\title{
Asylum Policy in the EU: The Case for Deeper Integration
}

\author{
By \\ Timothy J Hatton \\ (University of Essex and Australian National University)
}

\begin{abstract}
September 2014
ABSTRACT

Over the last fifteen years the locus of policy-making towards asylum seekers and refugees has shifted away from national governments and towards the EU as the Common European Asylum Policy has developed. Most of the focus has been on the harmonisation of policies relating to border control, the processing of asylum claims and reception standards for asylum seekers. But this still falls far short of a fully integrated EU-wide policy. This paper examines the basis upon which a joint EU policy can be justified. I then ask whether superior outcomes can be achieved by harmonisation alone or if more centralised policy-making is necessary. I chart the progress of harmonisation and burden-sharing in the development of the Common European Asylum System and explore its effects. I also study the political feasibility of deeper policy integration by analysing public attitudes in the European Social Survey. I conclude that deeper integration is both desirable and politically possible.
\end{abstract}

Keywords: Refugees, Asylum seekers, Asylum policy, Harmonisation, Burden-sharing JEL codes: F22, F53, F 55, H77, H87, J15

Acknowledgements: This paper was produced as part of the Centre for Economic Policy Research project on TEmporary Migration, integration and the role of POlicies (TEMPO), funded by the NORFACE research programme on Migration in Europe - Social, Economic, Cultural and Policy Dynamics. I am grateful to Mathias Czaika, Eiko Thielemann, and the Editors for useful comments as well as to participants at the CESIfo Conference on Migration in December 2013. 


\section{Introduction}

In the past two decades more than six million people have applied for asylum in the EU. The EU is the destination for around two thirds of all asylum seekers who find their way to the developed world. Their arrival has been attended by a sometimes heated debate that has ebbed and flowed in parallel with the volume of applications. In a number of countries it has spawned a political backlash that has led to ever tougher policies to restrict access to the border, to tighten up on the criteria for granting refugee status, and to circumscribe the terms and conditions under which asylum seekers subsist. During the 1980s and 1990s asylum policy was largely a matter for individual countries but in the late 1990s the EU embarked on a process to build a Common European Asylum System (CEAS). The ensuing years have witnessed a growing degree of harmonisation and cooperation in a number of strands of policy. But this still falls a long way short of a fully integrated asylum system.

There has been much debate about how the process should proceed and how deep cooperation should go. This paper addresses two sets of issues that are relevant to the debate. First, what is the underlying rationale for having a genuinely integrated asylum policy rather than policies that are decided and implemented by national governments? This is something that arises in a wide range of EU policy arenas and hence the same arguments may apply elsewhere. Nevertheless it is important to make the case for asylum. I argue that giving sanctuary to refugees can be seen as locally produced public good, which will be underprovided in the absence of cooperation. If there are strong arguments for a joint policy then the second question is: what form should it take? Specifically, is convergence in national policies enough or is there a case for a more centrally directed policy? I argue that there is a strong case for a more systematic policy of burden-sharing-something that would require greater central direction of asylum policy than is currently in prospect.

A second set of issues is whether the sorts of policies that the theory suggests are politically feasible. One indication is the trend towards deeper cooperation in the last decade. But it is also important to understand the motives that underpin public opinion towards asylum seekers and asylum policy. Here I use data from the European Social Survey for 2002/3 (a time of large asylum flows) to examine public attitudes. Perhaps more important still is the issue of whether voters in EU countries would be willing to see the responsibility for asylum policy transferred from their national government to the more centralised control of the EU. Surprisingly, in most countries a majority of the population prefers some form of international governance. That leaves the question of whether the EU could do better in implementing a policy that comes closer to the optimum. I argue that it could do, partly by escaping some of the more negative elements of national politics. I conclude that deeper integration of asylum policy in the EU is politically feasible and should be welcomed. 


\section{The case for cooperation}

Much of the literature on asylum and refugee policy is concerned with the prospects for cooperation between destination countries and countries of origin and transit. But one strand addresses the question of whether there is anything to be gained by closer cooperation among destination countries, particularly those in the EU, where joint policy is feasible (Suhrke 1998, Betts, 2003; Hatton 2004, 2011; Thielemann 2005, 2006; Thielemann and Derwan 2006; Czaika, 2009; Roper and Barria, 2010). The sources of possible gains to cooperation that are cited include reducing costs and uncertainty, minimising the deflection of asylum applicants from one destination to another, preserving international security, and the honouring international obligations such as the 1951 Refugee Convention. Most of the contributions invoke some sort of public good argument but it is sometimes unclear precisely how this translates into policy.

When policy is implemented by national governments the reference group is the people that elect them. Thus asylum policy must be analysed from the point of view of the electors of the destination countries. So why should the citizens of rich countries be willing to admit refugees? It is worth stressing the distinction between immigration policies and asylum policies. Immigration policy is often framed with reference to the (net) benefit to host populations, either to specific individuals, as in the case of family reunification, or to the economy, as in the case of labour migration. By contrast, refugees are admitted on the grounds of the benefit to them rather than to the host society. Thus the benefit to the host population comes through the humanitarian motive of protecting others from persecution. Such benefits are non-rival and non-excludable and hence providing a safe haven to refugees can be thought of as a public good. On these grounds residents of one country benefit from the knowledge that refugees also find safety in another country. ${ }^{1}$

This provides the motivation for a basic model of two symmetric host countries. The citizens of each country derive value from refugees in their own country and from those in the other country, but the cost of hosting refugees falls only on the country that admits them. The net valuations are:

$V_{1}=\alpha r_{1}-\beta r_{1}^{2}+\lambda r_{2}-c r_{1} ; \quad V_{2}=\alpha r_{2}-\beta r_{2}^{2}+\lambda r_{1}-c r_{2}$

Country 1's valuation, $V_{1}$, depends the number of refugees that it hosts, $r_{1}$, which is represented by a quadratic function of the number of refugees in order to reflect eventually diminishing tolerance for refugees locally. It also depends positively on the number of refugees that find a safe haven in country $2, r_{2}$, and negatively on the cost of refugees in country $1, c r_{1}$. Country 2 's valuation is described by an identical function with the same cost

\footnotetext{
${ }^{1}$ This does not necessarily rule out other sorts of externalities that have been raised in the literature such as security and public order.
} 
per refugee. In order to ensure that a positive number of refugees is chosen I assume that $\alpha$ $>c$.

The number of refugees depends on the overall 'demand' for asylum (arising from conditions in source and transit countries), on the destination preference of asylum seekers, and on each country's asylum policy.

$$
r_{1}=A s \gamma_{1} ; \quad r_{2}=A(1-s) \gamma_{2}
$$

Where $A$ is the total demand, $s$ is the share of asylum seekers preferring country 1 , and $\gamma(0<\gamma<1)$ reflects the country's asylum policy, where higher values represent more open or 'generous' policy. Tougher policies, as reflected by lower $\gamma$ deter asylum seekers either directly or indirectly. Thus the total number of refugees admitted, $R$, depends on total demand and a weighted average of policy.

$R=r_{1}+r_{2}=A\left[s \gamma_{1}+(1-s) \gamma_{2}\right]$

If each country chooses a policy to maximise its valuation independently of the other country, the non-cooperative policy settings are:

$$
\gamma_{1}^{N}=\frac{\alpha-c}{2 \beta A s} ; \quad \gamma_{2}^{N}=\frac{\alpha-c}{2 \beta A(1-s)}
$$

Thus a country's policy is tougher the higher is overall demand, the more that country is preferred as a destination, and the greater is the cost of refugees. Here both countries take the same number of refugees but their policies differ.

In (4) policies selected by each country take no account of the value of their refugees to the other country. The social optimum is obtained by maximising the sum of the two countries' valuations, $V_{1}+V_{2}$. This gives policy settings:

$\gamma_{1}^{*}=\frac{\alpha-c+\lambda}{2 \beta A s} ; \quad \gamma_{2}^{*}=\frac{\alpha-c+\lambda}{2 \beta A(1-s)}$

Asylum policies are more generous for both countries when the public good effects are taken into account through cooperative policy setting. In the social optimum the two countries still have different policies, as a result of the difference in asylum seeker preferences. The total number of refugees admitted, $R$, is higher by an amount $\lambda / B$.

If policies are harmonised then the two countries are constrained to have the same policy parameter, $\gamma_{1}=\gamma_{2}$. Suppose that country 1 is the preferred destination $(s>0.5)$ and it chooses the harmonised policy unilaterally. Then the harmonised policy will be:

$\gamma^{H N}=\frac{\alpha-c+\lambda(1-s) / s}{2 \beta A s}$

For country 1, this policy is more generous as compared with (4) above where there is no cooperation, but less generous than under the social optimum in (5). Policy could be more or 
less generous for country 2 than where there is no cooperation and the number of refugees it admits could be higher or lower. ${ }^{2}$ However the total number admitted by both countries combined is unambiguously lower than under the social optimum.

An alternative is to consider the case where the common policy parameter is chosen by the social planner. In that case $V_{1}+V_{2}$ is maximised with a common value for $\gamma$. The chosen policy will be:

$\gamma^{H C}=\frac{\alpha-c+\lambda}{2 \beta A\left(s^{2}+(1-s)^{2}\right)}$

With $s>0.5$ policy is less generous for country 1 and more generous for country 2 than under the social optimum (5) and there will be fewer refugees in total. As compared with the noncooperative case (4), policy is more generous for country 1 , it could be more or less generous for country 2 , and it could result in more or fewer refugees in total. ${ }^{3}$ Thus with harmonised policies it is not possible reach the social optimum and the total number of refugees admitted may even be less than in the case where policies are completely independent. In general, the greater is the imbalance in asylum seeker preferences (the greater is $s$ ) the further harmonised policies fall short of the social optimum.

It has often been suggested that financial burden-sharing could be helpful in getting closer to the social optimum. One form of burden-sharing is where countries contribute a lump sum to a common pool and then each take out an amount per refugee. This effectively reduces the marginal cost of refugees, which induces more generous asylum policies. In the case of independent policy setting, a subsidy per refugee equivalent to $\lambda$ would induce countries to shift from the policies in (4) to those in (5) thus achieving the social optimum. ${ }^{4}$ Because the optimum number of refugees is the same for both countries, the allocation from the common pool is divided equally. However, in the absence of harmonisation, policy will still differ between the two countries.

With harmonised policies uniform financial subsidies alone cannot produce the socially optimal number of refugees in each country. One alternative would be to have differential subsidies, which could provide a measure of compensation to each country. ${ }^{5}$ Another would be to set a common subsidy such that the harmonised policy would deliver the optimal number of refugees in total and then to redistribute refugees in order to arrive at the 'right' number for each country. If the form of harmonisation was that chosen by the social planner

\footnotetext{
2 The total number of refugees will be lower than in the non-cooperative case if: $(\alpha-c)(1-2 s)+\lambda(1-s) / s<0$. Thus the higher is $s$ (the greater is the imbalance in asylum seeker preferences) and the lower is $\lambda$, the more likely that this type of harmonisation would result in fewer refugees in total.

${ }^{3}$ The total number of refugees will be lower than in the non-cooperative case if $(\alpha-c+\lambda)-2(\alpha-c)\left(s^{2}+(1-s)^{2}\right)$ $<0$.

${ }^{4}$ In this case the total cost of subsidies would be $\lambda R$.

${ }^{5} \mathrm{~A}$ pair of subsidies can be chosen such that they produce the same total number of refugees as in the social optimum and that also compensates each country for not receiving its optimum share. This leads to somewhat more complex expressions for the two subsidy rates.
} 
in (7) above then the per-refugee subsidy would be an amount: $(\alpha-c+\lambda)\left[2\left(s^{2}+\right.\right.$ $\left.\left.(1-s)^{2}\right)-1\right]$. And the share of all refugees to be redistributed would be: $s-0.5$. A further possibility would be simply to impose from above the policy that delivers the optimal refugee total, without recourse to financial burden-sharing, and then to redistribute some of the refugees in order to obtain equal shares.

Several points are worth noting. One is that the model itself is rather basic. There are no deflection effects such that tougher policy in one country diverts asylum seekers to the other country. While this would make the model somewhat more complex it does not change the qualitative results (Hatton, 2011, pp. 116-121). Another assumption is that the cost and the valuation of refugees is the same in both countries. Differences in costs alone would make the model slightly more complex and it would mean that the optimal number of refugees would differ between the countries. But, again, it does not alter the basic insights.

Second, any move towards cooperation requires more central control over asylum policies as there is an incentive to free ride. Agreeing jointly on socially optimal policies as in (5) would require a monitoring system to ensure that neither country deviated from the agreed policy. Similarly, where policy is harmonised there is also an incentive to deviate. Financial burdensharing involves not only the monitoring of policy but also the administration of a central fund. Finally, the redistribution of refugees would involve even greater direct intervention in the form of a mechanism for redistribution. ${ }^{6}$ As will be outlined below, some of these elements are already in place although greater centralisation would be required in order to use them to reach the social optimum.

A third issue is whether countries would be willing to agree on asylum policies that maximise joint welfare. As Czaika (2009) notes, joint policies that achieve the social optimum in aggregate could (in some settings) leave one of the countries worse off than it would have been in the absence of cooperation. In that case the country would not be willing to enter into such an agreement. He shows that the more heterogeneous are the countries the more likely that the participation constraint will not be satisfied for both countries, something that would be consistent with the analysis of harmonisation policies above. ${ }^{7} \mathrm{He}$ also finds that the participation constraint may be tighter if countries can engage in side payments. Going further, Facchini et al. (2006) analyse a situation where voters in each country delegate to an elected representative the authority to negotiate international policy on their behalf. Joint welfare is increased when the representatives of each country bargain over the policy settings for both countries but, because of strategic delegation, the outcome still falls short of the

\footnotetext{
${ }^{6}$ In the rather different context of tradable quotas for refugees Fernández-Huertas Moraga and Rapoport (2013) provide a distribution mechanism that takes into account both the preferences of refugees and those of the receiving countries.

${ }^{7}$ Czaika (2009) assumes heterogeneity in (quadratic) asylum costs; in that case the participation constraint may not be satisfied even though policy is free to differ between countries. That is not true here, because under the policies in (4) and (5), for each country, the number of refugees (and hence welfare) is independent of the source of heterogeneity, $s$.
} 
social optimum. In this setting, introducing a financial burden-sharing scheme does not help because it exacerbates the effect of strategic delegation.

These analyses diverge from the reality of asylum policy in the EU in two respects. One is that they envisage a situation where the jointly set policies differ between countries, whereas the process of harmonisation has involved agreeing on policies that are the same or similar between countries. More important they focus on the case where country representatives set policy jointly whereas the issue in the $\mathrm{EU}$ is whether (or to what degree) member countries should cede policy-making authority to a supranational body over which they have little direct control. Clearly that body could be more or less conservative than the direct representatives would be, but it would surely attenuate the effects of strategic delegation.

As Suhrke (1998) notes, one of the reasons that burden-sharing failed in the 1990s was the lack of a hegemon to provide a strong lead in asylum policy (as the US did in the post-World War II and post-Vietnam refugee emergencies). It can be argued that given sufficient powers the EU could become the hegemon that was previously absent. Nevertheless, if some governments believed that EU policy would reduce their welfare from refugees, they might not be willing to cede the power to make asylum policy to a centralised authority in the first place. Czaika (2009) notes that the advent of qualified majority voting in the EU Council could accelerate the transition to a more centralised EU asylum policy. The trends in EU asylum policy are considered next.

\section{The evolution of policy}

Asylum applications surged in the 1980s, reaching a peak in 1992 and this led directly or indirectly to a policy backlash (Hatton, 2004). Even though all the countries of the EU were signatories of the 1951 Refugee Convention, its provisions left room for a considerable tightening of policy. This involved three dimensions. The first was the tightening of border controls through measures such as carrier sanctions, enhanced inspections and border patrols, and the introduction of special airport zones to quarantine potential asylum seekers. These were backed by the escalation of visa requirements for countries that were potential sources of asylum applicants.

The second strand of policy tightening was in the procedures that were used to determine whether or not an applicant would gain refugee status. This included narrowing the definition of a refugee, introducing fast track procedures for 'manifestly unfounded' claims, narrowing the scope for appeals and being less generous in awarding permission to stay on humanitarian grounds. As a result, the proportion of applicants to EU-15 countries who were granted some form of status fell from a half in 1985 to 30 percent a decade later. ${ }^{8}$ Third there was a progressive toughening of the conditions asylum seekers faced during the processing of their

\footnotetext{
${ }^{8}$ These are first instance decisions, see UNHCR Statistical Yearbook, 2001, Table C.30.
} 
applications. These included restricting access to employment, reducing welfare payments or substituting benefits in kind, and increasing use of detention.

Cooperation between EU countries on asylum policy gathered momentum in the early 1990s. In order to prevent asylum shopping, the Dublin Convention of 1990 established that an asylum claim would be assessed once, normally by the country of first entry. The resolutions made at a ministerial meeting in London in 1992 included a measure of agreement on designating as 'safe' certain countries of origin and of transit. Thus, applications of those arriving from or through such countries would normally be treated as manifestly unfounded and subject to a fast track procedure. ${ }^{9}$ In 1994 and 1995 EU ministerial agreements were reached on a number of other measures, the most important of which were readmission agreements with transit countries that were deemed to be safe (see Boswell, 2003a). These resolutions did not become binding until the end of the decade (1997 in the case of the Dublin Convention). Most countries introduced one or more packages of reforms during the 1990s. They often included other measures such as speeding up the procedures for assessing asylum claims, limiting the right of appeal, and more stringent enforcement of deportation for rejected applicants. Increasingly, restrictions were also placed on the living conditions of asylum seekers during the processing of claims including access to welfare benefits, freedom of movement (in some cases dispersal to designated centres) and the right to seek employment.

Although is possible to identify common trends in the asylum polices of the EU-15 countries during the 1990s formal cooperation was minimal. The common trends in tightening border controls and adopting tougher processing procedures owe more to the fact that the surge of asylum applications of the early 1990s was EU-wide. Consistent with the non-cooperative model above, countries reformed their policies in response to a rise in their own applications and those of other countries (Hatton, 2004, p. 31), a process that some observers saw as a 'race to the bottom' (Noll, 2000). Although there was some discussion of burden-sharing through refugee redistribution, nothing of substance followed (Boswell 2003b; Thielemann, 2003, Neumayer, 2004). The process towards more formal harmonisation began with the entry into force of the Treaty of Amsterdam in 1999. Transferring asylum policy from the third pillar to the first pillar gave the European Commission the right to propose legislation from 2002. Meanwhile the European Council meeting at Tampere in 1999 laid out plans to build a Common European Asylum System (CEAS) based on the 'full and inclusive' application of the 1951 Refugee Convention.

The first stage of the CEAS (the Tampere Programme) focused principally on the harmonisation of key elements of policy. The Reception Conditions Directive introduced common standards for access to employment and training, as well as to welfare, housing, health and education services for asylum seekers during the processing of their claims. A new version of the Dublin Regulation (Dublin II) revised the mechanism for determining the state

\footnotetext{
${ }^{9}$ For further details, see Oakley (2007).
} 
responsible for asylum claims, linked in with the EURODAC fingerprint database, which was established in 2003. The Qualification Directive provided a common set of criteria to be used in the adjudication of asylum applications, while the Asylum Procedures Directive laid down standards for designating claims as manifestly unfounded, as well as covering issues such as rights to appeal and to legal assistance. These directives were transposed within a set period into national legislation, but they laid down only minimum standards and they did not cover every aspect of the asylum process. Thus harmonisation was partial and incomplete.

Some first steps towards burden-sharing were introduced in the aftermath of the Kosovo crisis. ${ }^{10}$ In 2000 the European Refugee Fund was established. This is a common fund, most of which was allocated to countries according to the number of asylum seekers or refugees, to be used for refugee integration projects and to provide support for emergency temporary protection measures in the event of a mass influx of refugees. Originally funded for 2000-4, it was further extended and augmented with additional funds for facilitating reception and return and developing external border controls. Although the budget was, and remains, relatively small in relation to the total number of refugees, ${ }^{11}$ it may have helped a little to ease the participation constraint. ${ }^{12}$ The second measure was the Temporary Protection Directive, the purpose of which was to relocate refugees from countries under exceptional pressure in the event of a mass influx. However the directive does not provide an explicit formula for the redirection of refugees, relying instead on a 'balance of efforts' in a 'spirit of solidarity'. Nor is there a formal trigger to activate it, and thus it has never been invoked.

The second stage of the CEAS for 2004-10 (the Hague Programme) involved deeper cooperation in a number of areas. One is the establishment in 2005 of the of the FRONTEX agency, to integrate and standardise border control and surveillance operations. Another is the further harmonisation of rules and procedures for refugee status determination and appeals. A third initiative is extending reception standards in areas such as rights to social security, benefits, health and education. A fourth is promoting integration programmes for recognised refugees with increased financial support from the ERF. And fifth, new regulations have been promulgated on employer sanctions and on the return of illegal immigrants.

\footnotetext{
${ }^{10}$ Barutciski, M. and Suhrke, A. (2001) discuss the negotiations over burden-sharing during the during the refugee exodus from Kosovo that followed the NATO air strikes in 1999.

${ }^{11}$ The ERF was originally provided with a budget of $€ 216$ million over the five years $2000-4$, about a third distributed as a lump sum to member states and two-thirds according to the number applying or receiving some form of refugee status. But according to Noll (2003, p. 245): "Given the total costs of reception in the Member States and the share guaranteed to each Member State, the redistributive effects of the ERF are but a drop in the ocean. It must be praised as a dam-breaker construction with regard to the many dilemmas of fiscal burdensharing, but its practical role in creating predictability and reducing resort to restrictive migration and asylum policies is rather negligible" (Noll, 2003, p. 245). It was subsequently enhanced, with a budget of €604 million 2005-10, most of which was allocated according to the number of asylum seekers or refugees.

12 Thielemann (2005, p. 821) suggests that while the introduction of the ERF did little to induce countries to accept more refugees, it can be interpreted as a device to overcome potential resistance to policy harmonization.
} 
Before its completion, the Hague Programme was superseded by the Stockholm Programme, with the aim of completing the CEAS by $2012^{13}$. An important development was the establishment of the European Asylum Support Office (EASO), which is located in Malta and began operations at the end of 2010. This office is tasked with fostering the exchange of information and the dissemination of best practice methods as well as establishing an early warning system and mechanisms for supporting states that are under 'particular pressure'. Interestingly it is also expected to assist in the relocation of recognised refugees, but only on an 'agreed basis' between member states and with the consent of the individuals concerned. Subsequent developments include a revised Procedures Directive and a modification of the Dublin Regulation (Dublin III), which in principle takes account of the pressures faced by different countries.

Over the last decade considerable progress has been made in establishing the CEAS. However most of the focus has been on harmonisation of standards and procedures, something that EASO aims to further advance through its training programme. Nevertheless the application of these directives remains very uneven across the EU. ${ }^{14}$ Even less progress has been made in developing effective burden-sharing policies. The ERF has been strengthened but it remains relatively small and for that reason it is a weak instrument for financial burden-sharing. ${ }^{15}$ More importantly the responsibility for the implementation of most aspects of asylum policy remains firmly with the member states. While EASO has been given a coordinating role this stops far short of taking control of EU asylum policy and, as a result, central direction is highly circumscribed. ${ }^{16}$

\section{The distribution of asylum applications and burden-sharing}

It is well known that the burden of asylum seekers and refugees is unequally shared. Table 1 shows the average annual number of asylum applications for EU countries since 1996. For the

\footnotetext{
${ }^{13}$ The Stockholm Programme focused mainly on measures to combat illegal immigration, people smuggling and trafficking, as well as greater cooperation with states outside the EU. But it also envisaged some further steps in cooperation within the EU such as the joint processing of asylum applications, see: http://eurlex.europa.eu/LexUriServ/LexUriServ.do?uri=OJ:C:2010:115:0001:0038:en:PDF.

${ }^{14}$ For example the outcome of status determination procedures are very different in different receiving countries. Thus in 2009 the first instance recognition rates for Iraqis ranged from $3.3 \%$ in Greece and $19.1 \%$ in the UK to $42.2 \%$ in the Netherlands and $82.2 \%$ in France. A report by the UNHCR (2010) found that underlying these variations was the wide scope of the provisions of the Asylum Procedures Directive, which led to differences in the way that the Directive was transposed into national legislation. It also pointed to differences in the application of national rules. These include procedures relating to the right to a personal interview, interviewing methods, accelerated procedures, rights to appeal and effective remedies (see also Fundamental Rights Agency, 2010).

${ }^{15}$ For 2008-13, the ERF received an allocation of $€ 614$ million. Unlike its predecessor, this version included the possibility of distributing to a member state $€ 4,000$ per refugee for resettlement under certain circumstances. Two other funds have also been established, the European Integration Fund in 2007 and the European Return Fund in 2008. These funds are not specific only to asylum seekers and refugees.

${ }^{16}$ The Regulation that established EASO specifically states that: "The Support Office shall have no powers in relation to the taking of decisions by Member States' asylum authorities on individual applications for international protection," (Regulation 429/2010, Article 1 (6); for the full document, see: http://eurlex.europa.eu/LexUriServ/LexUriServ.do?uri=OJ:L:2010:132:0011:0028:EN:PDF).
} 
present EU-27 as a whole, the number of applications rose to a peak of 430,000 in 2001 and then declined. As a result total applications were much lower in 2006-10 than in either of the preceding five year periods. As the table shows, in some countries, such as Germany and the UK applications fell very steeply between 2001-5 and 2006-10 whereas in others such as France and Sweden the number increased. In absolute terms the incidence of asylum claims is very uneven across countries. The vast majority applications still go to the EU-15, although its share of the EU-27 fell from 94.2 percent in 1996-2000 to 90.6 percent in 2006-10.

Table 1: Annual Average Asylum Applications, by Five Year Periods

\begin{tabular}{|c|c|c|c|c|c|}
\hline & $1996-2000$ & $2001-5$ & $2006-10$ & $2006-10$ & 2006-10 \\
\hline & \multicolumn{3}{|c|}{ Asylum Applications (000s) } & Apps/Pop & Apps/GDP \\
\hline Austria & 13.2 & 29.8 & 13.0 & 1.56 & 0.044 \\
\hline Belgium & 24.9 & 18.3 & 14.4 & 1.35 & 0.041 \\
\hline Bulgaria & 0.9 & 1.8 & 0.9 & 0.11 & 0.010 \\
\hline Cyprus & 0.4 & 4.9 & 4.3 & 4.97 & 0.211 \\
\hline Czech Republic & 4.9 & 9.5 & 1.7 & 0.16 & 0.007 \\
\hline Denmark & 9.0 & 5.7 & 3.0 & 0.54 & 0.016 \\
\hline Estonia & 0.0 & 0.0 & 0.0 & 0.01 & 0.001 \\
\hline Finland & 1.8 & 3.1 & 3.5 & 0.67 & 0.021 \\
\hline France & 26.2 & 56.3 & 37.1 & 0.60 & 0.019 \\
\hline Germany & 98.6 & 54.9 & 26.3 & 0.32 & 0.010 \\
\hline Greece & 2.7 & 6.6 & 16.7 & 1.49 & 0.056 \\
\hline Hungary & 5.4 & 4.3 & 3.2 & 0.31 & 0.018 \\
\hline Ireland & 5.7 & 7.8 & 3.4 & 0.77 & 0.020 \\
\hline Italy & 12.5 & 11.7 & 16.1 & 0.27 & 0.010 \\
\hline Latvia & 0.0 & 0.0 & 0.0 & 0.02 & 0.001 \\
\hline Lithuania & 0.2 & 0.2 & 0.2 & 0.06 & 0.004 \\
\hline Luxembourg & 1.2 & 1.1 & 0.5 & 1.09 & 0.015 \\
\hline Malta & 0.1 & 0.6 & 1.6 & 3.80 & 0.172 \\
\hline Netherlands & 37.7 & 17.4 & 12.6 & 0.77 & 0.021 \\
\hline Poland & 3.5 & 6.3 & 7.2 & 0.19 & 0.012 \\
\hline Portugal & 0.3 & 0.3 & 0.2 & 0.02 & 0.001 \\
\hline Romania & 1.3 & 3.3 & 0.8 & 0.04 & 0.003 \\
\hline Slovak Republic & 0.9 & 6.6 & 1.6 & 0.29 & 0.015 \\
\hline Slovenia & 2.1 & 2.1 & 0.3 & 0.16 & 0.006 \\
\hline Spain & 6.5 & 10.0 & 4.6 & 0.10 & 0.004 \\
\hline Sweden & 11.2 & 29.2 & 28.2 & 3.07 & 0.091 \\
\hline United Kingdom & 65.4 & 65.2 & 28.1 & 0.46 & 0.014 \\
\hline EU-27 & 336.6 & 357.1 & 229.4 & 0.46 & 0.017 \\
\hline EU-15 & 316.9 & 317.4 & 207.8 & 0.53 & 0.017 \\
\hline
\end{tabular}

Sources: Data on the number of asylum applications are from UNHCR Statistical Yearbook, 2004, Table C31; and for later years from UNHCR "Asylum Levels and Trends in Industrialized Countries" (various years) at: http://esa.un.org/wpp/Excel-Data/population.htm. Population data is taken from the UN Population Database, 
2010 Revision at: http://esa.un.org/wpp/unpp/panel_population.htm. Real GDP in \$US (2000) data from the World Bank at: http://data.worldbank.org/indicator/NY.GDP.PCAP.KD.

Column (4) shows that there is also considerable variation in per capita terms. While 20 of the countries have less than one application per thousand of the population, Cyprus, Malta and Sweden have more than three per thousand. An alternative measure of capacity is applications per million dollars of GDP (column 5). Here too there is wide variation although the ranking of countries is slightly different. For the EU27 there is no evidence of convergence in the burden of applications. From 1996-2000 to 2006-10 the coefficient of variation of applications per capita increased from 1.08 to 1.43 and the coefficient of variation per unit of GDP increased from 0.84 to 1.62 . However there was modest convergence within the EU-15 where the coefficient of variation fell from 1.15 to 0.89 in per capita terms and from 0.88 to 0.75 per unit of GDP.

Policy probably contributed little to convergence in the EU15. In a study of the effects of policy in 19 OECD countries Hatton (2009) found that policies on access to the territory and on the toughness of asylum processing had significant deterrent effects on applications while policies on reception conditions did not. Among $11 \mathrm{EU}$ countries (the EU-15 excluding Finland, Greece, Luxembourg and Portugal), policy toughening from 2001 to 2006 reduced asylum applications by 78,000 out of a total fall of 222,000 . Thus policy accounted for more than a third of the fall and it contributed to convergence in the absolute number of applications. But in terms of applications per capita the coefficient of variation increased from 0.62 in 2001 to 0.92 in 2006. In the absence of any change in policy it would have increased only to $0.69 .{ }^{17}$

Thus in the recent past changes in asylum policies have done little to promote burden-sharing; if anything they seem to have done the opposite. This is consistent with the theoretical framework presented above, which suggests that policy harmonisation could lead to divergence in refugee burdens. ${ }^{18}$ The only existing distribution mechanism is that provided by the Dublin Regulation, which as noted above provides for the transfer or return of asylum applications to the country of first entry. This adds to the concentration of asylum claims of arrivals by land and sea in states on the EU border, and revisions to the regulation have done little to mitigate this effect. ${ }^{19}$ The pressure fell initially on countries like Germany and Austria on the EU's Eastern border, then on Poland, Spain, Italy and Greece, and most recently on the accession countries, Bulgaria, Romania, Cyprus and especially Malta. This has exacerbated the burden on smaller and poorer countries and has led to growing criticism.

\footnotetext{
${ }^{17}$ These calculations are based on the policy effects reported in Hatton (2009) Table 7. Other EU countries in the dataset included the Czech Republic, Hungary and Poland. If these are added then the coefficient of variation rises from 0.68 in 2001 to 1.03 in 2006; with no change in policy it would have risen to 0.84 .

${ }^{18}$ Bovens et al (2012) find that the cross country dispersion of refugee recognition rates actually increased from the early 2000s. The dispersion of applications also increased although inequality in the refugee burden across the EU declined.

19 The original proposal for Dublin III would have allowed for a temporary suspension of transfers towards states with limited reception and absorption capacities, but this was abandoned in favour of an early warning system for crisis management but without an alternative transfer mechanism.
} 
These concerns have led to further consideration of the possibility of redirecting asylum applications in order to even out the numbers, relative to some measure of capacity. One study for the EU Commission applied several different burden-sharing formulas to the data on asylum applications for 2008. The capacity measures include total population, GDP per capita and population density, which are combined with different sets of weights. ${ }^{20}$ These calculations imply that out of 242,000 asylum applications, between one third and 40 percent would be transferred from the country of original application (European Commission 2010, p. 30). A large share of the relocation would be from the EU-15 to the newer member states-a transfer that would amount to between 15 and 18 percent of the overall total.

Another report, this time for the European Parliament, uses a similar range of capacity measures to investigate the scale of potential transfers in 2007 (Thielemann et al., 2010, p. 127). In this case transfers of between 11 and 16 percent of the total inflow would be envisaged. They also examine scenarios where there is a financial transfer rather than physical relocation of refugees. As the model above illustrates, countries could be compensated to different degrees for excess burdens through a financial burden-sharing scheme. However as Thielemann et al. (2010, p. 47) point out this would involve vastly larger sums than are currently available through the ERF. According to their estimates the total amount to be distributed by the ERF to member states over the years 2008-13 is just 14 percent of asylum costs for the EU-27 for the single year 2007. They conclude that a policy of redistribution "is the only mechanism that is likely to have a real impact on the distribution of asylum costs and responsibilities across member states" (Thielemann et al., 2010, p. 143).

These comparisons raise several other issues. One is whether relocation should apply to asylum applicants or only to those recognised as refugees. Most governments evidently prefer the latter (European Commission, 2010, pp. 39-43). Although relocating asylum seekers would be more costly, it has the virtue of being a one-step procedure. Transferring applicants prior to determining their refugee status would also attenuate the incentive for an individual country to be 'too' generous in granting refugee status - in the knowledge that excess refugees would be transferred elsewhere. This also points to the importance of more complete harmonisation of asylum procedures, so that relocation would not imply radical differences in the probability of rejection. More complete harmonisation would be a necessary condition for gaining the consent of the asylum applicant to be transferred from one country to another, if consent was to be required.

A second issue is whether as system of 'voluntary pledging' on the part of governments would be preferable to a rule-based system of quotas or obligations. Although there have been some instances where countries have agreed to take more asylum applicants in a 'spirit of solidarity' the model set out above makes clear that an individual government has an incentive to free

\footnotetext{
${ }^{20} \mathrm{~A}$ burden-sharing formula along these lines was first suggested by Germany during its EU presidency in 1994, and was based on its internal mechanism for the distribution of refugees across the different Länder (Boswell, 2003, Thielemann, 2003; see also Czaika, 2005).
} 
ride. Thus, when choosing between alternative systems governments should choose the formula based-system to ensure that no individual country can free ride. Yet when asked, government representatives generally preferred a system of voluntary pledging (European Commission, 2010, pp. 39-43). Some of this caution reflected concerns about implementing such a scheme, in particular how 'quotas' would be set and revised, how transfers would be implemented and how much this would cost. ${ }^{21}$ But for the most part it reflected doubts about the political feasibility of ceding control of asylum policy. I return to this point further below.

\section{Who is against asylum seekers and refugees?}

It is widely believed that attitudes towards refugees are strongly negative and that this is a serious constraint for governments that might otherwise adopt more generous asylum policies. Here I look at the attitudes of respondents in the European Social Survey of 2002/3. In this wave only, the ESS asked a range of questions about immigration and asylum. As noted earlier this was a time when asylum applications had been relatively high and when there was a tightening of policy in a number of EU countries. For that reason we might expect attitudes to be more negative than at other times.

Table 2 shows the proportion of respondents that agreed or agreed strongly with the statement or that disagreed or disagreed strongly. When asked whether their country has more than its fair share of asylum seekers, more than 60 percent agreed, with over 70 percent for Greece, Ireland Luxembourg and the UK. On the other hand more than a third of respondents in Denmark and Finland disagreed, while less than ten percent did so in Greece Ireland and the UK. Across the countries in Table 2 there is a weak negative correlation $(-0.15)$ between the number of asylum applications per capita in the five years 1997-2001 and the proportion who believed that their country had more than its fair share. On the other hand the correlation between asylum applications per capita and the proportion who disagreed is also negative, but very small (-0.07).

\footnotetext{
${ }^{21}$ One particular issue noted by the report is the potential conflict between a policy of relocation and the Dublin Regulation noted above (revised as the Dublin II Regulation of 2003, and under further revision). Rather than trying to find a way of reconciling these it would be better to abandon the Dublin regulation altogether. In any case the Dublin System (which includes fingerprinting and registration with EURODAC) has been criticized because in most cases the requests made under the system are 'take back' meaning that the case has already been examined in another country, rather than 'take charge', where it has not (European Parliament, 2009). The system has been costly and time consuming, involving duplication of effort, and it has resulted in a low rate of transfers relative to requests. Perhaps more fundamentally, there are inward and outward transfers to most countries so that the overall net transfer is very small (European Commission, 2007).

Another potential issue is that of setting a fixed quota in the face of variations in the volume of applications over time and between countries. One solution would be to build a certain amount of slack into the system, so that individual country quotas add up to more than the anticipated total flow. Relocation from a given country would only take place once the ceiling had been reached. Quotas could be adjusted retrospectively in the light of the differences between a country's share of applications as compared with its share of the total quota.

As for the cost, the Commission's pilot study of transfers from Malta to France indicated an average cost of per person of nearly $€ 8,000$ (of which selection and travel is just over $€ 1,000$, and the rest is accommodation and other support costs) as compared with the $€ 4,000$ currently allowed for transfers under the ERF (European Commission, 2010, p. 63).
} 
On the question of whether the government should be generous in judging applications, Table 2 shows that opinion was more balanced with about a third agreeing. Again there is wide variation across countries with more than half of respondents in France, Poland and Portugal expressing agreement and less than a fifth disagreeing. The cross country correlation between applications per capita in 1997-2001 and the proportion that agreed with the statement is 0.35 , while the correlation with the proportion that disagreed is positive at 0.45 . Thus there is some evidence that voters think that the government should be generous when applications are low and tougher when applications are high, as the theoretical framework suggests.

Table 2: Attitudes in the European Social Survey 2002/3

\begin{tabular}{|l|r|r|r|r|}
\hline & \multicolumn{3}{|l|}{$\begin{array}{l}\text { Country has more than its fair } \\
\text { share of people applying for } \\
\text { refugee status }\end{array}$} & \multicolumn{2}{l}{$\begin{array}{l}\text { Government should be generous } \\
\text { judging applications for refugee } \\
\text { status }\end{array}$} \\
\hline Country & \% agree & \% disagree & \% agree & \% disagree \\
\hline Austria & 56.3 & 21.7 & 29.7 & 43.7 \\
\hline Belgium & 69.6 & 14.2 & 17.9 & 59.5 \\
\hline Czech Republic & 67.2 & 11.4 & 14.3 & 62.5 \\
\hline Denmark & 46.2 & 35.2 & 30.7 & 50.2 \\
\hline Finland & 41.9 & 33.9 & 33.4 & 33.1 \\
\hline France & 62.8 & 15.5 & 62.0 & 18.7 \\
\hline Germany & 64.9 & 15.4 & 15.1 & 60.8 \\
\hline Greece & 89.2 & 3.5 & 44.3 & 30.9 \\
\hline Hungary & 63.8 & 16.6 & 12.3 & 64.8 \\
\hline Ireland & 78.9 & 8.8 & 55.5 & 21.1 \\
\hline Italy & 54.6 & 16.4 & 26.2 & 38.1 \\
\hline Luxembourg & 75.9 & 11.2 & 30.9 & 45.6 \\
\hline Netherlands & 68.2 & 14.5 & 10.2 & 74.9 \\
\hline Poland & 40.3 & 25.6 & 63.1 & 13.0 \\
\hline Portugal & 56.5 & 17.6 & 59.0 & 12.9 \\
\hline Slovenia & 64.4 & 11.7 & 19.6 & 49.4 \\
\hline Spain & 64.5 & 15.0 & 48.3 & 19.6 \\
\hline Sweden & 47.2 & 22.1 & 41.5 & 23.1 \\
\hline United Kingdom & 82.2 & 5.9 & 28.0 & 46.6 \\
\hline Country average & 62.9 & 16.6 & 33.8 & 40.5 \\
\hline
\end{tabular}

Source ESS Round 1, edition 6/.2 from Norwegian Social Science Data Services at: http://ess.nsd.uib.no/.

What types of people hold negative or positive attitudes towards asylum seekers? The large literature on attitudes towards immigration points to both economic and social determinants. This literature typically finds that negative sentiment towards immigration is strongest among those with low education, among males and older people, and among those that are not themselves first or second generation immigrants. The literature interprets the effect of education in two ways. The first is that the less educated are concerned about the potential 
labour market competition from low skilled immigrants (Scheve and Slaughter, 2001; Mayda, 2006; O'Rourke and Sinnott, 2006). The other is that the more educated have greater tolerance towards minorities and are more positive about ethnic and cultural diversity (Dustmann and Preston, 2007; Hainmueller and Hiscox, 2007). Ortega and Polaveieja (2012) find evidence that both channels of influence are at work, particularly the former.

Studies of immigration opinion have found that concerns about the fiscal costs also weigh heavily with some citizens (Facchini and Mayda, 2009, 2012; Boeri, 2010). In particular they point to fears that higher immigration will lead to a higher tax burden. Consistent with these findings, some studies also suggest that the scale of immigration is an important determinant of negative attitudes, either at the aggregate level (Lahav, 2004; Sides and Citrin, 2007) or as a result of concentration in the respondent's local community (Dustman and Preston, 2001). There is also a variety of studies analysing attitudes to immigration in terms of political cultural and religious values. Almost all of the focus has been on attitudes to immigration rather than specifically to asylum. Here I analyse attitudes to asylum along similar lines.

Table 3: Explaining Attitudes to Asylum Seekers in the ESS 2002/3

\begin{tabular}{|l|r|r|r|r|}
\hline & \multicolumn{3}{|c|}{$\begin{array}{l}\text { Country has more than its fair } \\
\text { share of people applying for } \\
\text { refugee status }\end{array}$} & \multicolumn{2}{l|}{$\begin{array}{l}\text { Government should be } \\
\text { generous judging applications } \\
\text { for refugee status }\end{array}$} \\
\hline & $(1)$ & $(2)$ & $(3)$ & \multicolumn{1}{c|}{$(4)$} \\
\hline Age & 0.005 & 0.003 & -0.002 & -0.000 \\
& $(5.86)$ & $(3.71)$ & $(1.72)$ & $(0.02)$ \\
\hline Male & 0.012 & 0.018 & -0.073 & -0.056 \\
& $(0.66)$ & $(1.17)$ & $(3.38)$ & $(3.58)$ \\
\hline Citizen of country & 0.229 & 0.158 & -0.411 & -0.287 \\
& $(3.33)$ & $(2.80)$ & $(5.26)$ & $(4.41)$ \\
\hline Education level & -0.113 & -0.082 & 0.035 & 0.017 \\
& $(8.30)$ & $(6.51)$ & $(5.09)$ & $(2.10)$ \\
\hline Education $\times$ labour & -0.054 & -0.046 & 0.008 & 0.002 \\
participant & $(3.98)$ & $(3.56)$ & $(0.60)$ & $(0.21)$ \\
\hline Labour participant & 0.190 & 0.180 & -0.109 & -0.102 \\
& $(4.52)$ & $(4.59)$ & $(2.30)$ & $(2.33)$ \\
\hline Political right/left scale & & 0.041 & & -0.054 \\
& & $(4.35)$ & & $(7.42)$ \\
\hline Religious intensity & & -0.010 & & 0.023 \\
& & $(3.31)$ & & $(6.96)$ \\
\hline Feel unsafe & & 0.071 & & -0.043 \\
& & $(8.20)$ & & $(3.96)$ \\
\hline Share customs and & 30783 & 26885 & 33173 & 0.156 \\
traditions & & -0.251 & & $(10.05)$ \\
\hline Constant & & $(25.22)$ & & 3.017 \\
& & 3.923 & 3.329 & $(25.62)$ \\
\hline R 2 Within & & $(49.24)$ & $(33.69)$ & 0.06 \\
\hline Observations & & 0.14 & 0.01 & \\
\hline
\end{tabular}


Note: ' $\mathrm{t}$ ' statistics from robust standard errors clustered by country.

Table 3 presents regressions with country fixed effects for the attitudes towards asylum that were summarized in Table 2. The dependent variable takes five values, where 5 is 'strongly agree' and 1 is 'strongly disagree'. ${ }^{22}$ In the first column the dependent variable is 'more than fair share' and the signs of the coefficients on age (in years), male citizen and education are consistent with the typical findings in the literature on attitudes to immigration. Education is an ordinal variable for the individual's highest level of education (less than lower secondary = 1 ; completed tertiary $=5$ ) based on the ISCED classification. This variable is also interacted with a dummy taking the value one if the individual was in the labour force. Both coefficients are positive and the latter can be interpreted as a labour market competition effect: the more educated the worker, the less he or she would fear competition from asylum seekers. Thus between the lowest and highest education groups the difference in opinion amounts to -0.67 points for labour market participants and -0.45 points for non-participants. The separate coefficient on the labour participation dummy is negative-an effect that could be interpreted as representing concerns about the tax implications of hosting refugees.

The second column adds a number of other attitudinal variables that have been utilised in the literature on immigration opinion. ${ }^{23}$ The individual's self-placement on the political spectrum ( 0 = far left; $10=$ far right) is strongly positive and it clearly has a powerful effect. Thus, shifting from far left to far right raises the dependent variable by 0.4 points. The coefficient on the intensity of religious belief (not at all religious $=0$; very religious $=10$ ) is positive, perhaps reflecting greater compassion, but the effect is small compared with that of political stance. A variable on whether the individual feels safe walking alone at night (very safe $=1$ very unsafe $=4$ ) is intended to capture the feeling of insecurity underlying the notion that asylum seekers are a potential threat to an individual's safety. The coefficient is significant in the expected direction although its magnitude is modest. Finally, the response to the question as to whether it is better for the country if almost everyone shares the same culture and traditions (agree strongly =1; disagree strongly $=5$ ) captures the sense that the majority culture is under challenge. This has a powerful and highly significant effect, again in the expected direction.

These results suggest that attitudes towards asylum seekers are shaped partly by political and religious perspectives and by feelings of personal or cultural insecurity. But the results of regressing one type of attitude on another cannot be interpreted as causal, as they all stem from deeper psychological and social roots. In the absence of appropriate instruments it is not possible to make causal inferences. However it is worth noting the effects on the other variables when these attitudinal variables are included. The coefficient on education becomes a little smaller, perhaps because of its correlation with insecurity and attitudes to ethnic minorities. On the other hand the effect of labour force participation is little affected. Thus

\footnotetext{
22 The results of estimating with ordered probit are qualitatively similar to those in Table 3. But the marginal effects are more difficult to interpret and hence they are not presented here.

${ }^{23}$ For reviews of this literature, see Ceobanu and Escandell (2010) and Hainmueller and Hopkins (2014).
} 
when other attitudinal variables are included they do not overturn the effects of variables representing education and labour force participation.

The third and fourth columns show the results of applying the same set of explanatory variables to the question as to whether the government should be generous to in assessing asylum claims. Here the signs should be the opposite of those in columns (1) and (2). In column (3) the effect of education is smaller and the interaction with labour force participation is not significant. Thus views about the determination of asylum claims seem to be less associated with the individual's skill level and hence with the threat of labour market competition. On the other hand labour market participation is negative and significant, perhaps reflecting concerns about the potential cost. When the attitudinal variables are added in column (4) the pattern is similar to that in column (2) although religious intensity is a little more important and insecurity and customs and traditions are a little less important.

\section{Who is in favour of international policy-making?}

The model outlined above suggests that greater welfare could be attained if refugee and asylum policy was determined centrally, so that the public good element is taken fully into account. That would require an even more radical shift away from national decision making and towards decision making at the EU level. As we have seen national governments seem to be reluctant to cede control of asylum policies, perhaps because they fear that this would make them even more unpopular. Here I look at whether this would be justified on the basis of public opinion.

The European Social Survey for 2002/3 asked what political level they would prefer for decision making on immigration and refugee policy. The levels are international, European, national or regional/local. Unfortunately the question was not asked separately for asylum seekers and other immigrants. ${ }^{24}$ Nevertheless the results are striking. On average across the EU countries in Table 4 nearly a third of respondents wished to see immigration and refugee policy decided at the international level while more than a quarter specified Europe as the appropriate locus for decision-making. The country average for either international or European level policies is well over a half. Thus there appears to be quite strong support for supra-national policy making on immigration and asylum. Among the countries listed in Table 4 , thirteen out of nineteen had a majority in favour of supra-national policy and only Finland and Sweden registered less than 40 percent in favour. On the face of it, this suggests that there would be considerable support for more centralised policy-making.

There are two potential caveats. First, it is possible that these opinions do not represent genuine support for more centralised policies. Respondents might have interpreted the

\footnotetext{
${ }^{24}$ In the 2005-8 World Values Survey asked a specific question about 'who should decide' on refugees. I have not used that here because the alternatives to the national government were regional organizations or the UNHCR. However the proportions preferring the national government were even lower than those in Table 2 . The EU countries (and percentages) are: Italy (35.1), Spain (14.0), Sweden (34.0), Finland (44.0), Slovenia (22.9), Bulgaria (17.0), Romania (39.9), Germany (26.4) and Cyprus (41.8).
} 
question as meaning that that immigrants and refugees would no longer be the responsibility of their particular country and that instead they would be taken in by other countries. This would be consistent with the finding in Table 2 that more than 60 percent of respondents agreed or strongly agreed that their country was receiving more than its fair share of applicants for asylum. The correlation across countries between the proportion believing that their country was receiving more than its fair share and the proportion preferring decision making at the international or European level is 0.19 . However across individuals in the survey the correlation is slightly negative at -0.07 . Thus it seems that those who favoured supranational decision making did not do so simply to reduce what they saw as an inequitable burden.

Table 4: Preferred Level for Decisions on Immigration and Refugee Policy in the European Social Survey 2002/3

\begin{tabular}{|l|r|r|r|r|}
\hline & $\begin{array}{l}\text { International } \\
\text { level }\end{array}$ & $\begin{array}{l}\text { European } \\
\text { level }\end{array}$ & $\begin{array}{l}\text { International } \\
\text { or European } \\
\text { level }\end{array}$ & $\begin{array}{l}\text { Regional, } \\
\text { national or } \\
\text { local level }\end{array}$ \\
\hline Austria & 28.4 & 29.7 & 58.0 & 42.0 \\
\hline Belgium & 39.8 & 34.0 & 73.8 & 26.2 \\
\hline Czech Republic & 35.5 & 26.3 & 61.8 & 38.2 \\
\hline Denmark & 18.6 & 28.9 & 47.4 & 52.6 \\
\hline Finland & 14.0 & 17.6 & 31.6 & 68.4 \\
\hline France & 39.9 & 30.9 & 70.9 & 29.1 \\
\hline Germany & 24.1 & 31.5 & 55.6 & 44.4 \\
\hline Greece & 33.3 & 29.9 & 63.1 & 36.9 \\
\hline Hungary & 23.4 & 23.6 & 47.1 & 52.9 \\
\hline Ireland & 23.6 & 20.9 & 44.5 & 55.5 \\
\hline Italy & 30.8 & 31.1 & 61.9 & 38.1 \\
\hline Luxembourg & 36.4 & 27.2 & 63.6 & 36.4 \\
\hline Netherlands & 37.4 & 35.0 & 72.4 & 27.6 \\
\hline Poland & 49.2 & 23.4 & 72.7 & 27.3 \\
\hline Portugal & 39.8 & 31.3 & 71.0 & 29.0 \\
\hline Slovenia & 31.3 & 29.4 & 60.7 & 39.3 \\
\hline Spain & 44.4 & 22.1 & 66.6 & 33.4 \\
\hline Sweden & 17.5 & 21.3 & 38.8 & 61.2 \\
\hline United Kingdom & 31.8 & 15.9 & 47.7 & 52.3 \\
\hline Average & 31.5 & 26.8 & 58.4 & 41.6 \\
\hline
\end{tabular}

Source ESS Round 1, edition 6/.2 from Norwegian Social Science Data Services at: http://ess.nsd.uib.no/.

Second, it is possible that positive opinions about international decision making might apply to a wide range of policies including those where there is no externality or public good element. The attitudes towards international decision-making over immigration and asylum can be compared with those on other policy areas where the ESS asked the same question. In three areas an even greater percentage wanted to see policy decided at the international or 
European level-environmental protection (60.0), the fight against organised crime (71.8), and aid to developing countries (76.10). These country averages (not weighted by population) can be compared with the country mean for immigration and asylum of 58.2 percent, with defence only a little lower at 55.1. These are all arguably areas where there are gains (in the sense outlined above) to setting policy at the international level. By contrast for social welfare policies, where the policy gains are less obvious, the country average was only 26.8 percent. In two areas where there common EU policies do exist, but where the social gains are less clear, the averages are also lower: agriculture (40.9) and interest rates (45.6).

Table 5: Explaining Preferred Decision Levels for Immigration and Asylum Policy in the ESS 2002/3

\begin{tabular}{|c|c|c|c|c|}
\hline & \multicolumn{2}{|c|}{$\begin{array}{l}\text { International or European } \\
\text { level }\end{array}$} & \multicolumn{2}{|c|}{ European Level } \\
\hline & (1) & $(2)$ & (3) & $(4)$ \\
\hline Age & $\begin{array}{r}-0.002 \\
(6.11) \\
\end{array}$ & $\begin{array}{r}-0.001 \\
(3.11)\end{array}$ & $\begin{array}{r}-0.000 \\
(0.14) \\
\end{array}$ & $\begin{array}{l}0.001 \\
(1.98) \\
\end{array}$ \\
\hline Male & $\begin{array}{l}0.004 \\
(0.44)\end{array}$ & $\begin{array}{r}-0.009 \\
(1.03)\end{array}$ & $\begin{array}{l}0.028 \\
(5.97)\end{array}$ & $\begin{array}{l}0.025 \\
(5.84)\end{array}$ \\
\hline Citizen of country & $\begin{array}{r}-0.030 \\
(2.52) \\
\end{array}$ & $\begin{array}{r}-0.035 \\
(2.24) \\
\end{array}$ & $\begin{array}{r}-0.019 \\
(1.60 \\
\end{array}$ & $\begin{array}{r}-0.032 \\
(1.78) \\
\end{array}$ \\
\hline Education level & $\begin{array}{l}0.041 \\
(6.23)\end{array}$ & $\begin{array}{l}0.022 \\
(4.47)\end{array}$ & $\begin{array}{l}0.025 \\
(6.25)\end{array}$ & $\begin{array}{l}0.019 \\
(4.02)\end{array}$ \\
\hline $\begin{array}{l}\text { Education } \times \text { labour } \\
\text { participant }\end{array}$ & $\begin{array}{r}-0.010 \\
(1.66)\end{array}$ & $\begin{array}{r}-0.002 \\
(0.32)\end{array}$ & $\begin{array}{l}0.002 \\
(0.39)\end{array}$ & $\begin{array}{l}0.002 \\
(0.48)\end{array}$ \\
\hline Labour participant & $\begin{array}{l}0.039 \\
(1.98)\end{array}$ & $\begin{array}{l}0.008 \\
(0.40)\end{array}$ & $\begin{array}{l}0.005 \\
(0.27)\end{array}$ & $\begin{array}{l}0.001 \\
(0.05)\end{array}$ \\
\hline Political right/left scale & & $\begin{array}{r}-0.007 \\
(2.75)\end{array}$ & & $\begin{array}{l}0.000 \\
(0.00)\end{array}$ \\
\hline Religious intensity & & $\begin{array}{r}-0.000 \\
(0.09)\end{array}$ & & $\begin{array}{r}-0.000 \\
(0.48)\end{array}$ \\
\hline Feel unsafe & & $\begin{array}{r}-0.006 \\
(0.96)\end{array}$ & & $\begin{array}{r}-0.005 \\
(1.05)\end{array}$ \\
\hline $\begin{array}{l}\text { Share customs and } \\
\text { traditions }\end{array}$ & & $\begin{array}{l}0.021 \\
(4.24)\end{array}$ & & $\begin{array}{l}0.008 \\
(2.86)\end{array}$ \\
\hline Trust in national parliament & & $\begin{array}{r}0.002 \\
(1.14) \\
\end{array}$ & & $\begin{array}{r}0.005 \\
(3.18) \\
\end{array}$ \\
\hline $\begin{array}{l}\text { Trust in European } \\
\text { parliament }\end{array}$ & & $\begin{array}{l}0.018 \\
(7.48) \\
\end{array}$ & & $\begin{array}{l}0.010 \\
(6.41)\end{array}$ \\
\hline Constant & $\begin{array}{r}0.561 \\
(15.42)\end{array}$ & $\begin{array}{r}0.500 \\
(11.26)\end{array}$ & $\begin{array}{l}0.182 \\
(7.06)\end{array}$ & $\begin{array}{l}0.121 \\
(3.59)\end{array}$ \\
\hline $\mathrm{R}^{2}$ Within & 0.022 & 0.024 & 0.008 & 0.013 \\
\hline Observations & 35201 & 25567 & 35201 & 26567 \\
\hline
\end{tabular}

Note: ' $\mathrm{t}$ ' statistics from robust standard errors clustered by country. 
It is worth analysing the opinions on the decision level for immigration and asylum along the same lines as those for attitudes to asylum seekers. A key question is whether the same variables that influence negative attitudes to asylum seekers are also associated with a reluctance to see decisions made at the international level. In the first two columns of Table 5 the dependent variable takes the value 1 if the respondent prefers decisions to be made at either the international or the European level. In the third and fourth columns the dependent variable takes the value 1 only for the European level.

The result in column (1) shows that age and citizenship are associated with greater reluctance to cede decision making power away from the national government. Education has a significant positive influence but its effect is fairly small. Going from lowest to highest education levels increases the probability by only 0.16 . Labour force participation alone and interacted with education has small and insignificant effects. On the interpretation set out earlier concerns about labour market competition and the fiscal costs are relatively unimportant. A set of attitudinal variables are added in column (2). Of the four attitudinal variables that were included in Table 3 only political right/left scale and fears about shared customs and traditions are significant. Here, two additional variables are added representing the degree of trust in the national parliament and in the European parliament (no trust at all $=0$; complete trust $=10$ ). An interesting finding is that the strongest correlation is for trust in the European Parliament while trust in the national parliament, which might be predicted to be negative, is positive and not significant.

The results for the European level (relative to either national or international) are shown in columns (3) and (4). These are broadly similar although there is a surp risingly strong positive effect for males. Interestingly, the correlation with political right/left disappears while the trust in the national parliament becomes positive. It is worth stressing again that the effects of attitudinal variables cannot be interpreted as causal. Nevertheless the results suggest that lack of trust in the policy making at the EU level is a principal motive behind the reluctance to cede power over asylum policy to the EU. If that underlying mistrust could be overcome then public opinion might favour EU-level asylum policy even more.

\section{Could the EU do better?}

Whether or not a more integrated and centralised EU asylum policy would produce outcomes closer to the social optimum requires some understanding of how policy is set at the national level and how far that would differ from policy set by the EU. This question has two components. One is whether (and why) policy set by national governments is excessively restrictive. The other is whether policy making at the EU would likely be more enlightened.

There is a large literature on policy making at the national level, most of which relates to immigration in rather than asylum. One line of argument typically draws on the analysis of individual attitudes in surveys such as the ESS examined above (e.g. Sides and Citrin 2006). If applied to trends over time these would suggest, if anything, that attitudes would become 
more liberal as education increases and prejudice decreases over time. As we have seen, attitudes towards asylum seekers are also associated with fears about personal safety or crime, threats to security and challenges to the majority culture, but core values have not changed very much. Attitudes to asylum seekers may have become more negative over time because of the increase in the numbers but it is also due to the fact that the term asylum seeker has become conflated with illegal immigrant and welfare cheat. ${ }^{25}$ Such concerns have been given greater salience by negative press coverage, often about the apparently preferential treatment given to refugees in the form of public welfare housing and other social services, together with a thinly veiled undercurrent of racism and xenophobia. ${ }^{26}$

One key indicator is support for extreme right wing parties for whom immigration and asylum is a central policy issue. There was a surge in support for right wing parties during the 1990s and another one in the early 2000s, just as asylum applications were reaching a second peak. In the latter period these included Freedom Party in Austria, the Danish Peoples Party in Denmark, the List Pym Fortuyn in the Netherlands and the Vlams Belang in Belgium as well as the Front National in France and a little later the Liga Nord in Italy. More recently significant gains have been made by the True Finns, the Sweden Democrats, the Netherlands Freedom Party, the Norway Progress Party and Golden Dawn in Greece. For Europe as a whole the vote share of populist right parties grew from around 10 percent in the early 2000s to reach 15 percent in 2011.

The literature identifies strong links between anti-immigration attitudes and support for extreme right-wing parties (Knigge, 1998; Lubbers at al., 2002; Kessler and Freeman, 2005; Iversflaten, 2008; Rydgren, 2008). Yet, with some exceptions, these parties have not gained enough electoral power to become part of the government coalitions that implement policy. In most countries their main influence has been in shifting the agendas of mainstream parties, both on the left and the right (Schain 2006; Van Spanje 2010). What little quantitative evidence there is on the policy outcomes supports the view that, across Europe, surges in far right votes are associated with tougher asylum policies (Neumayer, 2005; Hatton, 2011, pp. 63-66).

These observations suggest that mainstream political parties, led by liberal-minded elites, might be willing to cede control over asylum to the EU in order to take some of the heat out of domestic politics and deflect pressure from the far right. ${ }^{27}$ But one strand of the literature

\footnotetext{
${ }^{25}$ One study of opinion in the UK found that: "There is a popular assumption that the vast majority of asylum seekers are not in fear of persecution and should not be claiming asylum. In part this stems from confusion over the legal status of an asylum seeker. Many people in the focus groups understood 'genuine' to refer to the way someone entered the UK. They therefore assumed that anyone entering 'illegally' (for example hidden in a lorry) is not a genuine asylum seeker. There was also generally poor knowledge about international issues. Virtually no participant mentioned events such as the wars in Iraq or Afghanistan as potential drivers of asylum" (Lewis, 2005, p. 14).

${ }^{26}$ For an analysis of press coverage in the UK, see Greenslade (2005).

${ }^{27}$ This would be consistent the view of immigration politics expressed by Freeman (1995) who observed that the strong anti-populist norm of client politics came under pressure with the asylum crisis of the 1990s.
} 
argues exactly the opposite. It suggests instead that national governments are constrained by domestic institutions (such as the courts) that uphold the legal rights of asylum seekers and that prevent them from implementing asylum policies that are even tougher and more exclusionary. An alternative is to shift the locus of policy-making to the EU where national governments are influential relative to liberal EU institutions and where there is less external scrutiny. This presents the opportunity to sidestep domestic constraints, achieving national policy objectives at the expense of national sovereignty (Guiraudon 2000). Givens and Luedtke (2004) find some evidence that when the salience of immigration and asylum is high, restrictive harmonisation policies are more likely to be proposed in the EU and adopted. However this evidence is for 1999 to 2002 when asylum demand was high (which would lead to tougher policies anyway) and it does not compare the restrictiveness of the harmonised policies with those that governments would have implemented in the absence of harmonisation.

One way to examine the effect of transferring policy to the EU level is see how the introduction of reforms under the harmonisation process of the CEAS actually affected specific elements of policy in member states. Thielemann and El Enany (2009) examine the implementation of several of the key directives. For the introduction of the Reception Directive (2003) they found evidence that 10 countries were obliged to improve their standards significantly while another three improved to a lesser extent and in a further three there was some element of downgrading. Upgrading involved improved access to employment, health and education, and enhanced protection for vulnerable groups. They also found that the Qualification Directive (2004) led to some widening of the criteria for granting refugee status or subsidiary protection, notably in France and Germany. Similarly, the Procedures Directive (2005) safeguarded the right to information, representation and appeal, while the Return Directive (2008) forced some countries to shorten the length of (re)entry bans and to provide the right to appeal. ${ }^{28}$

Thielemann and El Enany (2009, p. 24) conclude that "Rather than leading to policy harmonisation at the 'lowest common denominator', EU asylum laws have frequently led to an upgrading of domestic asylum laws in several Member States, strengthening protection standards for several groups of forced migrants, even in the case of EU laws that have been widely criticised for their restrictive character." Such results are consistent with the effects of harmonisation policies represented by equations (6) or (7) above, although in neither of these cases is the social optimum reached. It is possible that policy would have eased anyway, as a result of the fall in demand for asylum, which according to the model should have made policy more generous. Nevertheless the results stand in sharp contrast with the widespread view that harmonisation has typically involved tougher policies. That impression seems to be largely due to the criticisms levelled at the directives by organisations such as the UNHCR, the

\footnotetext{
${ }^{28}$ Luedke (2009) studied the introduction of directives on Long term Residents and Family Reunification. Here too he result was to make policy more restrictive for some countries but more generous for others (especially the 2004 accession countries).
} 
European Council for Refugees and Exiles and Amnesty International. The arguments of these and other advocate groups for more generous provisions do not necessarily imply that the directives were more restrictive than existing policy.

In the past decade harmonisation in asylum policy seems to have had the sorts of effects that are predicted by the model. But to fully internalise the public good element deeper integration would be necessary. Although the establishment of EASO is an important step forward, providing assistance, advice and logistical support does not constitute taking control of asylum policy. A truly European asylum policy would require deeper harmonisation of procedures and standards across the whole range of asylum policies (some of which is in progress), as well as a stronger monitoring system. More importantly, it would require a centrally operated burden-sharing mechanism including a formula for redistributing asylum applications that would replace the Dublin Regulation, the logistics of which are already in place. One model would be to establish an EU-financed EASO 'cell' in each country so that centrally determined policy could be implemented through existing administrative structures.

Are such developments remotely possible? There are two elements. The first is whether EU institutions are likely to favour more liberal asylum policies than national governments. The second is whether the EU has sufficient power to gain the upper hand in setting policy. On the first point, the embedded 'communitarianism' of EU institutions suggests that their policy preferences would be aligned with those of the social planner. Among the key institutions, the European Commission is committed to upholding the 'common interest', notably in the field of Justice and Home Affairs. The rise in the importance of humanitarian and antidiscrimination issues is reflected by the entry into force in 2009 of the EU Charter of Human Rights and the inauguration in 2007 of the Fundamental Rights Agency. It is also reflected in recent decisions of the European Court of Justice (Collins 2009, see also Caporaso and Tarrow, 2009) and in the Commission's action plan for implementing the Stockholm Programme (Kostakopoulou, 2010). Policy development within the EU is also influenced by a variety of well-organised interest groups and NGOs such as the UNHCR and the European Council for Refugees and Exiles, which are often represented in the European Commission's Expert Groups. While the EU is often criticised as suffering from a democratic deficit, in the refugee arena this typically works in favour of humanitarianism and against the xenophobic pressures that face many national governments.

On the second point, following the Amsterdam Treaty the European Commission gained the exclusive right to propose new legislation. The Hague Programme saw the introduction of qualified majority voting on asylum policy in the EU Council and the establishment of codecision rights for the European Parliament. The Lisbon Treaty further enhanced the centralisation of asylum and refugee policy, which underpins the Stockholm Programme. These developments may create even greater divergence between the policy objectives of EU institutions and national governments (Leconte 2008), although this will likely be tempered where there is a public good element to policy. And while the European Parliament may 
remain sceptical of further integration, ${ }^{29}$ this will be attenuated by the application of qualified majority voting in the European Council. Perhaps more important is the momentum that has been built over the last decade and that has been carried forward under in the Stockholm Programme. As Luedtke (2009) points out, "creeping jurisdiction" works in the Commission's favour. Having established a legal basis it is possible later to upgrade it - as with the Reception and Qualification Directives. Thus, initially anaemic frameworks such as the Temporary Protection Directive, the ERF and EASO could provide the foundation on which to build a much stronger element of burden-sharing into CEAS.

\section{Conclusion}

This paper has examined the question of joint asylum policy within the EU from a number of angles. The first point is that the theoretical basis for cooperation among host countries over asylum policy rests on the notion that refugees can be seen as a public good. In a framework with public good effects cooperative policy making can, in principle, produce socially optimal asylum policies, whereas independent national policy-making cannot. In this setting harmonising the policies of individual countries makes it impossible to reach the social optimum in the absence of some form of burden-sharing, either through a common financial pool or, more effectively, through refugee transfers.

This view has important implications for the past and future development of the Common European Asylum System. The CEAS has developed largely through policy harmonisation with only a small burden-sharing element. Partly as a result, the pattern of asylum applications remains highly unbalanced between countries, something that existing policies have failed to address. While significant progress has been made, doubts remain about whether or not a fully integrated policy that ceded to a central authority the allocation of asylum claims would be politically feasible to member states.

Data from the ESS shows that public opinion towards asylum policy was on balance negative in 2002/3, when the volume of asylum claims was relatively high. At the individual level negative attitudes are associated with economic position, political affiliation and cultural attitudes. Despite this, a surprisingly large proportion of voters would prefer to see asylum and immigration policies set at the supra-national level. Thus the political feasibility of a fully integrated asylum system may be greater than is often believed.

Tougher national asylum polices have been associated with increases in the salience of asylum and with electoral gains by far right parties. But despite some views to the contrary,

\footnotetext{
${ }^{29}$ Lahav and Messina (2005, p. 863) find that, as of 2004, 40 percent of MEPs thought that the responsibility for regulating immigration policy should reside exclusively with national governments while another 40 percent thought that it should reside with EU institutions on the basis of a majority vote. This represents the same level of support for EU-level policy as a decade earlier. However, the recent European elections may have shifted that balance.
} 
harmonisation has not simply been a race to the bottom. Recent trends in EU asylum policies have laid some of the foundations for a more centralised policy. That could involve ceding more direct authority to EASO and using the mechanism of the Dublin Regulation to redistribute asylum claims according to different criteria. These mechanisms could be used to attain something closer to the social optimum, an outcome that could also become politically feasible in the foreseeable future. 


\section{References}

Barutciski, M. and Suhrke, A. (2001), "Lessons from the Kosovo Refugee Crisis: Innovations in Protection and Burden-Sharing," Journal of Refugee Studies, 14, pp. 95-134.

Betts, A. (2003), "Public Goods Theory and the Provision of Refugee Protection: The Role of the Joint-Product Model in Burden-Sharing Theory," Journal of Refugee Studies, 16, pp. 274296.

Boeri, T. (2010), "Immigration to the Land of Redistribution," Economica, 77, pp. 651-87.

Boswell, C. (2003a), "The 'External Dimension' of EU Immigration and Asylum Policy," International Affairs, 79, pp. 619-38.

Boswell, C. (2003b), "Burden-Sharing in the European Union: Lessons from the German and UK Experience," Journal of Refugee Studies, 16, pp. 316-335.

Boswell, C. (2008), "Evasion, Reinterpretation and Decoupling: European Commission Responses to the 'External Dimension' of Immigration and Asylum," West European Politics, 31, pp. 491-512.

Bovens, L., Chatkupt, C. and Smead, L. (2012), "Measuring Common Standards and Equal Responsibility-sharing in EU Asylum Outcome Data," European Union Politics, 13, pp. 70-93.

Caporaso, J. A. and Tarrow, S. (2009), "Polanyi in Brussels: Supranational Institutions and the Embedding of Markets," International Organisation, 63, pp. 593-620.

Ceobanu, A. M. and Escandell, X. (2010), "Comparative Analyses of Public Attitudes Toward Immigrants and Immigration Using Multinational Survey Data: A Review of Theories and Research," Annual Review of Sociology, 36, pp. 309-28.

Czaika, M. (2005), “A Refugee Burden Index: Methodology and its Application', Migration Letters, 2, pp. 101-25.

Czaika, M. (2009), "Asylum Cooperation among Asymmetric Countries: The Case of the European Union," European Union Politics, 10, pp. 89-113.

Collins, A. M. (2009) "Recent Developments in Asylum and Immigration Law before the Court of Justice," ERA Forum, 9, pp. 581-590.

Dustmann, C. and Preston, I. (2001), "Attitudes to Ethnic Minorities, Ethnic Context and Location Decisions," Economic Journal, 111, pp. 353-373.

Dustmann, C. and Preston, I. (2007), "Racial and Economic Factors in Attitudes to Immigration," Berkeley Electronic Journal of Economic Analysis and Policy, 7, Article 62. 
European Commission (2007) "Report from the Commission to the European Parliament and the Council on the Evaluation of the Dublin System," at:

http://www.en.refugeelawreader.org/index.php?option=com content\&view=article\&id=81 \&ltemid $=207$.

European Commission (2010), Study on the Feasibility of Establishing a Mechanism for the Relocation of Beneficiaries of International Protection, JLX/2009/ERFX/PR/1005, Copenhagen: Directorate General of Home Affairs.

European Parliament (Directorate-General Internal Policies, Citizens Rights and Constitutional Affairs) (2009), "Reflection Note on the Evaluation of the Dublin System and on the Dublin III Proposal," at: http://www.ulb.ac.be/assoc/odysseus/CEAS/PE410.690.pdf.

Facchini, G., Lorz, O. and Willmann, G. (2006), "Asylum Seekers in Europe: The Warm Glow of a Hot Potato," Journal of Population Economics, 19, pp. 411-30.

Facchini, G. and Mayda, A. M. (2009), "Does the Welfare State Affect Individual Attitudes toward Immigrants?" Review of Economics and Statistics, 91, pp. 295-314.

Facchini, G. and Mayda, A. M. (2012), "Individual Attitudes towards Skilled Migration: An Empirical Analysis across Countries," World Economy, 35, pp. 183-196.

Fernández-Huertas Moraga, J. and Rapoport, H. (2013), "Tradable Immigration Quotas," Munich: CESIfo working paper 4087.

Freeman, G. P. (1995), "Modes of Immigration Politics in Liberal Democratic States," International Migration Review, 29, pp. 881-902.

Fundamental Rights Agency (2010), “Access to Effective Remedies: The Asylum Seeker Perspective," at: http://fra.europa.eu/fraWebsite/attachments/report-accessremedies EN.pdf.

Greenslade, R. (2005), "Seeking Scapegoats: The Coverage of Asylum in the UK Press," Asylum and Migration Working Paper No 5, Institute for Public Policy Research, London.

Givens, T. and Luedtke, A. (2004), 'The Politics of European Union Immigration Policy: Institutions, Salience, and Harmonization," Policy Studies Journal, 32, pp. 145-165.

Guiraudon, V. (2000), "European Integration and Migration Policy: Vertical Policy-making as Venue Shopping," Journal of Common Market Studies, 38, pp. 251-271.

Hainmueller, J. and Hiscox, M. J. (2007), "Educated Preferences: Explaining Individual Attitudes toward Immigration in Europe," International Organization, 61, pp. 399-442.

Hainmueller, J. and Hopkins, D. (2014), "Public Attitudes toward Immigration," Annual Review of Political Science, 17, pp. 11.1-11.25. 
Hatton, T. J. (2004), "Seeking Asylum in Europe," Economic Policy, 38, pp. 5-62.

Hatton, T. J. (2009), "The Rise and Fall of Asylum: What Happened and Why," Economic Journal, 119, pp. F183-F213.

Hatton T. J. (2011), Seeking Asylum: Trends and Policies in the OECD, London: Centre for Economic Policy Research, at: http://www.cepr.org/pubs/books/cepr/Seeking Asylum.pdf. Ivarsflaten, E. (2008), "What Unites Right-Wing Populists in Western Europe? Re-Examining Grievance Mobilization Models in Seven Successful Cases," Comparative Political Studies, 41, pp. 3-23.

Kessler, A. E. and Freeman, G. P. (2005), "Support for Extreme Right Wing Parties in Western Europe: Individual Attributes, Political Attitudes, and National Context," Comparative European Politics, 3, pp. 261-88.

Kostakopoulou, D. (2010), "An Open and Secure Europe? Fixity and Fissures in the Area of Freedom, Security and Justice after Lisbon and Stockholm," European Security, 19, pp. 151167.

Knigge, P. (1998), 'The Ecological Correlates of Right-Wing Extremism in Western Europe', European Journal of Political Research 34, pp. 249-79.

Lahav, G. (2004), "Public Opinion toward Immigration in the European Union: Does it Matter?" Comparative Political Studies, 37, pp. 1151-1183.

Lahav, G. and Messina, A. M. (2005), "The Limits of a European Immigration Policy: Elite Opinion and Agendas within the European Parliament," Journal of Common Market Studies, 43, pp. 851-875.

Leconte, C. (2008) "Opposing Integration on Matters of Social and Normative Preferences: A New Dimension of Political Contestation in the EU," Journal of Common Market Studies, 46, pp. 1071-1091.

Lubbers, M., Gijsberts, M. and Scheepers, P. (2002), "Extreme Right-wing Voting in Western Europe," European Journal of Political Research, 41, pp. 345-78.

Luedtke, A. (2009), "Uncovering European Union Immigration Legislation: Policy Dynamics and Outcomes," International Migration, 49, pp. 1-27.

Neumayer, E. (2004), “Asylum Destination Choice: What Makes some West European Countries More Attractive than Others?" European Union Politics, 5, pp. 155-180.

Neumayer, E. (2005), "Asylum Recognition Rates in Western Europe: Their Determinants, Variation and Lack of Convergence," Journal of Conflict Resolution, 49, pp. 43-66. 
Noll, G. (2000), Negotiating Asylum: The EU Acquis, Extraterritorial Protection and the Common Market of Deflection, The Hague: Martinus Nijhof.

Noll, G. (2003), "Risky Games? A Theoretical Approach to Burden-Sharing in the Asylum Field," Journal of Refugee Studies, 16, pp. 236-52.

Oakley, S. (2007), "Accelerated Procedures for Asylum in the European Union: Fairness versus Efficiency," University of Sussex Migration Working Paper no. 43.

Ortega, F. and Polavieja, J. G. (2012),"Labor-market Exposure as a Determinant of Attitudes toward Immigration," Labour Economics, 19, pp. 298-311.

Roper, S. D. and Barria, L. A. (2010), "Burden Sharing in the UNHCR: Refugee Protection as an Impure Public Good," Journal of Conflict Resolution, 54, pp. 616-637.

Rydgren, J. (2008), "Immigration Sceptics, Xenophobes or Racists? Radical Right-Wing Voting in Six West European Countries," European Journal of Political Research 47, pp. 737-65.

Schain, M. A. (2006), "The Extreme-Right and Immigration Policy-making: Measuring Direct and Indirect Effects," West European Politics, 29, pp. 270-289.

Scheve, K. F. and Slaughter, M. J. (2001), "Labor Market Competition and Individual Preferences over Immigration Policy," Review of Economics and Statistic, 83, pp. 133-45.

Sides, J. and Citrin, J. (2007), "European Opinion about Immigration: The Role of Identities, Interests and Information," British Journal of Political Science 37, pp. 477-504.

Suhrke A. (1998), "Responsibility-sharing during Refugee Emergencies: The Logic of Collective Action versus National Action," Journal of Refugee Studies, pp. 396-415.

Thielemann, E. (2003), "Between Interests and Norms: Explaining Patterns of BurdenSharing in Europe, Journal of Refugee Studies, 16, pp. 253-73.

Thielemann, E. (2005), "Symbolic Politics or Effective Burden-sharing? Redistribution, Sidepayments and the European Refugee Fund," Journal of Common Market Studies, 43, pp. 807-824.

Thielemann, E. and Dewan, T. (2006), "The Myth of Free-riding: Refugee Protection and Implicit Burden-sharing," West European Politics, 29, pp. 351-369.

Thielemann, E. and El-Enany, N. (2009), "Beyond Fortress Europe? How European Cooperation Strengthens Refugee Protection," London School of Economics: unpublished paper. 
Thielemann, E., Williams, R. and Boswell, C. (2010), "What System of Burden-sharing between Member States for the Reception of Asylum Seekers?" Brussels: European Parliament Directorate for internal Affairs.

UNHCR (2001, 2004), Statistical Yearbook, (Series), Geneva: United Nations High Commissioner for Refugees.

UNHCR (2010), "Improving Asylum Procedures: A comparative Analysis and Recommendations for Law and Practice," at: http://www.unhcr.org/4ba9d99d9.html.

Van Spanje, J. (2010), “Contagious Parties: Anti-Immigration Parties and their Impact on Other Parties' Immigration Stances in Contemporary Western Europe," Party Politics, 16, pp. 563-586 